\title{
INDONESIAN PEER TO PEER LENDING (P2P) AT ENTRANT'S DISRUPTIVE TRAJECTORY ${ }^{\square}$
}

\author{
Cliff KOHARDINATA ${ }^{\circledR 1}$, Noorlailie SOEWARNO ${ }^{\circledR 2}$, Bambang TJAHJADI ${ }^{3^{*}}$ \\ 1, 2, ${ }^{3}$ Faculty of Economics and Business, Universitas Airlangga, Surabaya, Indonesia \\ ${ }^{1}$ Faculty of Management and Business, Universitas Ciputra, Surabaya, Indonesia
}

Received 09 September 2019; accepted 30 December 2019

\begin{abstract}
Peer to peer (P2P) lending in Indonesia has been growing rapidly, therefore there is the potential for disruptive innovation processes in the financial sector. The aim of this study is to examine the impact of the growth of P2P lending on the growth of bank lending for micro, small and medium enterprises (MSME) and Non-MSME debtors. Separating the scale of the debtor is important, given the initial process of disruptive innovation of reaching areas that are not the incumbent's main target. The examination was conducted in this study using panel data regression, whereby the examination was done in stages. This was an overall examination without differentiating between the regions, further examination conducted with more detail by separating between the loans inside and outside Java Island. This is because the economic structure in Indonesia is still dominated by the regions in Java, but FinTech is generally able to grow in areas with less developed local economies. The result of this study is consistent overall, Java and outside Java Island, as shows that the growth in P2P lending in Indonesia does not have a significant impact on the growth of bank loans for Non-MSME lending. However, it does have a negative impact on the growth of bank loans for MSME lending. This is in line with the entrant's disruptive trajectory process by which the entrants enter the competition through an underserved market (niche markets) and not through the main target market of the incumbent (MSME).
\end{abstract}

Keywords: banking, disruptive innovation, FinTech, P2P lending, MSME, Non MSME.

JEL Classification: G21, G23, O33.

\section{Introduction}

Financial technology (FinTech) obtaining to the peer to peer (P2P) lending market is moving faster in developing countries. This is, because the penetration of financial services in Asian countries is lower due to the unfamiliarity with the banking sector and also the geographical or infrastructure challenges (Gupta \& Xia, 2018; Stern, Makinen, \& Qian, 2017), including in Indonesia. P2P in Indonesia has grown, but its presence of $\mathrm{P} 2 \mathrm{P}$ shows a positive response from society for the $\mathrm{P} 2 \mathrm{P}$ facility itself. The accumulation of P2P loans in Indonesia grew rapidly from Rp 3,002.55 billion in January 2018 to Rp 37,013.39 billion in April 2019, which is Rp 34,010.84 billion or growth of $1,132.73 \%$ over the past 16 months (Keuangan, 2019). Peer to peer platforms can help the government to increase the level of financial inclusion in Indonesia but this does not mean that a peer to peer platform is not a threat to existing financial businesses (Banking).
Digitalisation in the banking sector has recently faced a new round with the emergence of thousands of start-up FinTech companies around the world (Stern et al., 2017). The perception of the FinTech revolution is rather contradictory. Some members of the financial services industry see FinTech's growth as a threat to the traditional banking sector. While others see that FinTech can turn into an opportunity because it provides more flexibility and better functionality in several banking fields (Romānova \& Kudinska, 2017).

Fintech-based loans (P2P) have kept on growing and they can serve the small and medium enterprises segment as well as debtors with low income (Ramlall, 2018). However, banking in general is more selective and cautious at providing loans and therefore the loan is more likely to be disbursed to non-MSME debtors (Montgomery, Squires, \& Syed, 2018; Zhang, Hu, \& Chang, 2019), including in Indonesia. The initial process of disruptive innovation (entrant's disruptive trajectory) can have a

\footnotetext{
$\overline{0}$ This article has been corrected since first published. Please see the statement of correction https://doi.org/10.3846/btp.2021.14272.
}

*Corresponding author. E-mail: bambang.tjahjadi@feb.unair.ac.id

This is an Open Access article distributed under the terms of the Creative Commons Attribution License (http://creativecommons.org/licenses/by/4.0/), which permits unrestricted use, distribution, and reproduction in any medium, provided the original author and source are credited. 
certain appeal for different and previously ignored customer segments (low end) which then penetrate to the mainstream and high end market (Christensen et al., 2015; Govindarajan \& Kopalle, 2006; Lee \& Shin, 2018; Zalan \& Toufaily, 2017). Therefore, there is the opportunity for FinTech (P2P) to enter into the larger financial sector market through technology to serve the previously underserved markets who are not the primary target of the incumbent banks.

The initial process of disruptive innovation (entrant's disruptive trajectory) is often not realised and ignored because established companies are more focused on their innovations for main consumer needs. However, this early process of disruptive innovation is important to understand as a preventive effort from the banking management (financial institutions) perspective to determine future strategy and to strengthen their competitive advantage, as well as for the government to establish regulations to adapt to the changing financial landscape. The growth of P2P lending in China can be a lesson to be more cautious in the initial process of disruptive innovation. Zhang et al. (2019) mentioned that P2P in China had a positive impact on the initial regime. However, $\mathrm{P} 2 \mathrm{P}$ loans had a negative impact on the subsequent regime when the P2P loans grew bigger.

This study will examine the effect of P2P loans on the loans disbursed by banking that are separated based on debtor scale, which are the MSME (Micro, Small and Medium Enterprises) and non-MSME scales respectively. This research divided the debtors to find out the initial process of disruptive innovation with the consideration that disruptive innovation starts the process of disruption through small scale or unreachable markets. The examination is conducted in stages, starting from the overall evaluation, followed by a more detailed evaluation done by separating based on regions between Java and non-Java Island, since the economic structure in Indonesia in the year 2018 is still dominated by the regions in Java with a gross domestic product contribution of 58.48 percent (Statistik, 2019). In general, FinTech is able to grow in regions with a less favourable local economy (Jagtiani \& Lemieux, 2018) because FinTech is boundless and low cost.

\section{Literature review}

Many established companies have recognised the need for innovation and they have created procedures, processes or even formed research and development departments to explore new technologies and opportunities (Das et al., 2018). In an environment with high turbulence, successful innovations can equip companies with superior performance and competitive advantages. An interest in financial innovation has become increasingly important with the latest developments in the financial and banking business. It has become important that banking institutions should try to increase their innovation arsenal (Abir, Raoudha, \& Emna, 2016). FinTech is an innovation that plays a role in changing the financial and banking landscape and many start-up businesses use FinTech to enter the financial industry whose impact on incumbents is not yet unpredictable.

\subsection{Disruptive innovation}

Figure 1 shows the innovation matrix based on the problem definition and domain definition consisting of the basic research strategy aimed to discover something completely new, whereby the problem or domain are not defined properly. The breakthrough innovation strategy can be used when the problem can be properly defined but hard to solve, so therefore an idea or expertise from another field is needed. Sustaining an innovation strategy can be used to improve on the existing technology or innovation to allow it to be better. Disruptive innovation is a product or service that changes the basis of competition because the performance of its product or service is lower based on traditional parameters. However, it can become better based on the new parameter that was previously deemed unimportant (Satell, 2017).

\begin{tabular}{|c|c|c|c|c|}
\hline \multirow{3}{*}{ 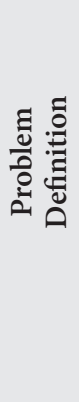 } & & $\begin{array}{l}\text { Not Well } \\
\text { Defined }\end{array}$ & $\begin{array}{c}\text { Well } \\
\text { Defined }\end{array}$ & \multirow[b]{3}{*}{ 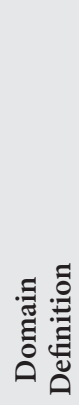 } \\
\hline & 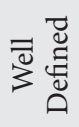 & $\begin{array}{l}\text { Breakthrough } \\
\text { Innovation }\end{array}$ & $\begin{array}{l}\text { Sustaining } \\
\text { Innovation }\end{array}$ & \\
\hline & 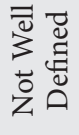 & $\begin{array}{c}\text { Basic } \\
\text { Research }\end{array}$ & $\begin{array}{l}\text { Disruptive } \\
\text { Innovation }\end{array}$ & \\
\hline
\end{tabular}

Figure 1. Innovation Matrix (source: Satell, 2017)

Many researchers use the term "disruptive innovation" to describe any situation in which the industry is shaken and where incumbents who were previously successful stumbled. However, that is much too broad a usage. Disruptive innovation explain a process through which smaller companies with fewer resources can successfully challenge established incumbent businesses (Christensen et al., 2015). Similar to disruptive innovation, the process of disruptive technology enters the market with a different value proposition compared to the previously existing companies. Generally disruptive technology is positioned under established products, but they do have new features that yield customer value. Products based on disruptive technology are usually cheaper, simple and more convenient for use (Christensen, 1997).

Figure 2 is a disruptive innovation model that shows that incumbent companies can give better products or service quality for the high-end market (with highest profitability) that exceeds the needs of low end and mainstream customers. Entrants on the disruptive trajectory then improve their offer and performance to move on to the higher market (with highest profitability) and they thus 


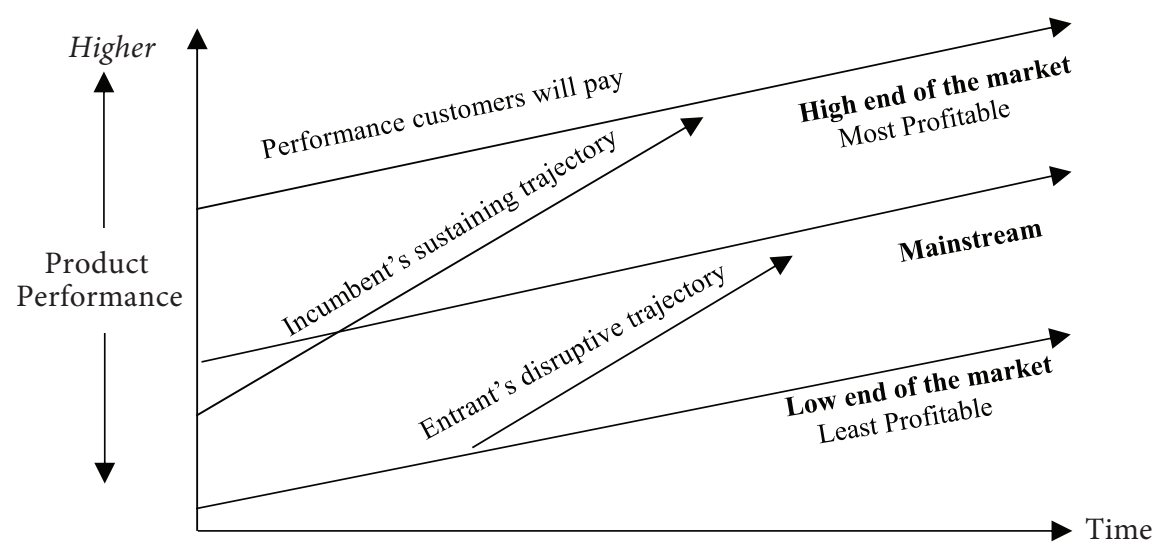

Figure 2. The disruptive innovation model (source: Christensen et al., 2015)

then challenge the domination of established companies (Anagnostopoulos, 2018; Christensen \& Raynor, 2003; Christensen et al., 2015; King \& Baatartogtokh, 2015; Rasool et al., 2018). Incumbents are typically not interested in creating and developing their own disruptive innovations that promise target smaller markets, lower margins and the introduction of inferior services and products that their existing customers cannot use (Christensen et al., 2016). This condition has opened up opportunities for newcomers to enter through less profitable segments (generally that are cheaper, less complicated and easier to access) and they are also ignored by established companies.

\subsection{Fintech (P2P Lending) and banks}

Digitalisation in the banking sector recently experienced a new twist with the emergence of thousands of start-ups worldwide. Financial technology (FinTech) is an important innovation in the finance industry that brings new paradigm by taking advantage of information technology especially in increasing service quality (Gai, Qiu, \& Sun, 2018; Lee \& Shin, 2018). Loan innovation offered through FinTech is often called marketplace lending, whereby the potential borrower can look for loans through a peer to peer (P2P) platform on the internet (Stern et al., 2017; Ramlall, 2018).

FinTech has become an integral part of the financial and banking industry (Romānova \& Kudinska, 2017). However, the effect of P2P loans on the banking industry still varies. There is a possibility that P2P lending won't affect the banking industry, but on the other hand, it is possible that P2P lending has a complementary or substitution effect (Li et al., 2017; Jagtiani \& Lemieux, 2018). Thus, the development of FinTech and its impact on the future of banking is a very important and interesting topical nowadays (Romānova \& Kudinska, 2017).

\subsubsection{P2P has no effect on bank loans}

Big banks are often worried about disbursing loans to micro, small and medium enterprises due to the information asymmetry that could arise from the financial reports. For that reason, a shadow bank innovated by providing loans to those who were not previously served (Tan, 2017; Wu \& Hua, 2018). The FinTech-based P2P platform really helped micro, small and medium enterprises to gain access to loans (Song et al., 2018). The P2P loan target market is very different from the bank target market, which is one possible reason why $\mathrm{P} 2 \mathrm{P}$ lending doesn't and won't have an effect on bank loans.

P2P lending does not affect bank loans, which can also indicate that the new entrant entities are still too small to become competitors against the big established banks. Aside from that, established banks also gain an advantage from their ability to maintain a credit line easily with the power that they already have (Li et al., 2017). Das (2017) mentioned that entrants (FinTech) can be a competitive threat for banks but the condition is not always so mature as to be a threat. Many Fintech innovations are released to maintain or improve on an existing product, but as long as the banks have the incentive to adopt those innovations, then it would be hard for newcomers to be a threat to established banks. FinTech has a very massive and broad managerial and technical impact. This does not mean that incumbent banks cannot compete with FinTech, banks already have a reasonably good level of innovation readiness (Iman, 2019).

\subsubsection{Substitution Effect of P2P on bank loans}

FinTech has brought in a new paradigm whereby information technology encourages innovation in the financial sector. FinTech is repeatedly mentioned as a disruptive innovation that can disrupt the traditional financial market (Lee \& Shin, 2018). FinTech companies can provide financial services directly to the customer and they can disrupt and change the pre-existing channels. They can also threaten the continuity of banking business (Coetzee, 2018; Ryu, 2018). The fact that financial intermediaries (banks) are not involved in the process of P2P lending means that with the rapid growth of the P2P loan balance and with a need for the convenience given by P2P lending, this causes the potential bank customers to choose loans from P2P platform and therefore the effect of P2P lending on the banks is competitive (Lavryk, 2016; Zhang et al., 
2019). The financial and banking sector that does not anticipate the threat from FinTech through changes in their business strategy will face the risk of losing customers or potential customers.

\subsubsection{Complementary effect of P2P on the banking sector.}

FinTech and traditional banking are complementary rather than an interplay of substitution and disruptive innovation (Li et al., 2017). The result of the interview conducted by Zalan and Toufaily (2017) with executives in both the FinTech and banking sector shows that FinTech cannot succeed without banks. Similarly, banks need FinTech start-ups (CEO FinTech). Senior technology and service managers in a commercial bank stated that banking can and should integrate with the banking sector. Although FinTech is often seen of as a threat to traditional financial institutions, it can actually provide many opportunities to gain competitive advantage. The majority of big financial companies are starting to take FinTech seriously and they are developing strategies to compete, coexist and collaborate with FinTech start-ups (Lee \& Shin, 2018). Zhang et al. (2019) showed that when the loan balance for P2P is low, it will have a positive impact on bank loan balance. Indonesia is in the early stages of FinTech growth, and therefore, the initial hypothesis used in this study would echo Zhang et al. (2019) that stated that P2P lending will have a positive impact on banking loan in the initial regime of FinTech's growth.

\section{Research methodology and data}

This study was conducted using the monthly cross-section and time series data between from Feb 2018 to Apr 2019, therefore this study used panel data regression to examine the model. The impact of P2P lending on bank loans for MSME and non-MSME debtors has been described in the main model of the panel data below:

$$
\begin{aligned}
& \text { Model 1: } \triangle \text { MSME it }= \\
& \alpha+\beta 1 \Delta \mathrm{P} 2 \mathrm{P} \text { it }+\beta 2 \Delta \mathrm{M} 2 \text { it }+\beta 3 \mathrm{INF} \text { it }+\varepsilon \text { it; } \\
& \text { Model 2: } \Delta \text { Non }- \text { MSME it }= \\
& \alpha+\beta 1 \Delta \mathrm{P} 2 \mathrm{P} \text { it }+\beta 2 \Delta \mathrm{M} 2 \text { it }+\beta 3 \mathrm{INF} \text { it }+\varepsilon \text { it; } \\
& \text { Model 3: } \triangle \text { MSME it }= \\
& \alpha+\beta 1 \Delta \mathrm{P} 2 \mathrm{P} \text { it }+\beta 2 \Delta \mathrm{M} 2 \text { it }+\beta 3 \text { INF it }+ \\
& \beta 4 \mathrm{D}_{\mathrm{HMSME}}+\beta 5 \mathrm{D}_{\mathrm{MSME}}+\varepsilon i \mathrm{i} \text {; } \\
& \text { Model 4: } \triangle \text { Non }- \text { MSME it }= \\
& \alpha+\beta 1 \Delta \mathrm{P} 2 \mathrm{P} \text { it }+\beta 2 \Delta \mathrm{M} 2 \text { it }+\beta 3 \text { INF it }+ \\
& \beta 4 \mathrm{D}_{\mathrm{HMSME}}+\beta 5 \mathrm{D}_{\mathrm{MSME}}+\varepsilon i \mathrm{it} \text {. }
\end{aligned}
$$

The detailed description of the research model is as displayed in Table 1. The bank loan variable consists of a loan disbursed by the bank to MSME and non-MSME debtors recorded by the Financial Services Authority in each of the 33 provinces, as displayed in Table 2. The P2P loan variable used is the total accumulated P2P loans within and outside of Java Island as recorded by Financial
Services Authority. As displayed in Table 1, we control for macroeconomic variables which consist of growth

\begin{tabular}{|c|c|}
\hline Variable & Measurement \\
\hline \multicolumn{2}{|c|}{ Dependent Variable } \\
\hline $\begin{array}{l}\text { Banking loan for } \\
\text { MSME ( } \triangle \text { MSME) }\end{array}$ & $\begin{array}{l}\text { \% Monthly growth of bank loans for } \\
\text { the MSME debtors in each provinces }\end{array}$ \\
\hline $\begin{array}{l}\text { Banking loan for non- } \\
\text { MSME ( } \triangle \text { Non-MSME) }\end{array}$ & $\begin{array}{l}\text { \% Monthly growth of bank loans } \\
\text { for non-MSME debtors in each } \\
\text { provinces }\end{array}$ \\
\hline \multicolumn{2}{|c|}{ Independent Variable } \\
\hline P2P loans $(\Delta \mathrm{P} 2 \mathrm{P})$ & $\begin{array}{l}\text { \% Monthly growth of P2P loan } \\
\text { accumulation in Java and Non-Java } \\
\text { Island (real growth) }\end{array}$ \\
\hline \multicolumn{2}{|c|}{ Control Variable } \\
\hline Money supply $(\Delta \mathrm{M} 2)$ & $\begin{array}{l}\text { \% Monthly growth of money supply } \\
\text { in Indonesia }\end{array}$ \\
\hline Inflation (INF) & Monthly inflation rate (\%) \\
\hline $\begin{array}{l}\text { DHMSME (Dummy } \\
\text { High Low MSME) }\end{array}$ & $\begin{array}{l}\text { Dummy variable that equals } 1 \text { if } \\
\text { growth of bank loans for the MSME } \\
\text { is larger than median and } 0 \text { otherwise }\end{array}$ \\
\hline $\begin{array}{l}\text { DMSME } \\
\text { (Dummy MSME) }\end{array}$ & $\begin{array}{l}\text { Dummy variable that equals } 1 \text { if } \\
\text { growth of bank loans for the MSME } \\
>\text { growth of bank loans for the Non- } \\
\text { MSME and } 0 \text { otherwise }\end{array}$ \\
\hline \multicolumn{2}{|l|}{ Number of province (i) } \\
\hline Number of month (t) & \\
\hline
\end{tabular}
of money supply and inflation rate, and we have used dummy variables to categorise MSME and Non-MSME in each province. DHMSE is the first dummy variable to categorise high and low growth of bank loan for MSME, and DMSME is the second dummy variable to categorise whether the growth of bank loan is higher or lower between MSME and Non-MSME.

Table 1. Variable and measurement (source: compiled by the authors)

Table 2. Provinces in Java and Non-Java Island (source: Zakky, 2018)

\begin{tabular}{|l|l|}
\hline \multicolumn{1}{|c|}{ Island } & \multicolumn{1}{c|}{ Provinces } \\
\hline Java & $\begin{array}{l}\text { West Java, Banten, DKI Jakarta, D.I Yogyakarta, } \\
\text { Central Java, East Java. }\end{array}$ \\
\hline $\begin{array}{l}\text { Outside } \\
\text { Java }\end{array}$ & $\begin{array}{l}\text { Bengkulu, Jambi, Aceh, North Sumatera, West Su- } \\
\text { matera, Riau, Riau Islands, South Sumatera, Bangka } \\
\text { Belitung, Lampung, South Kalimantan, West Kali- } \\
\text { mantan, East Kalimantan, Central Kalimantan, } \\
\text { Central Sulawesi, South Sulawesi, North Sulawesi, } \\
\text { Southeast Sulawesi, West Sulawesi, Gorontalo, West } \\
\text { Nusa Tenggara, Bali, East Nusa Tenggara, Maluku, } \\
\text { Papua, North Maluku, West Papua. }\end{array}$ \\
\hline
\end{tabular}

Measurement was in \% growth to be able to capture the initial potential of $\mathrm{P} 2 \mathrm{P}$ lending growth that impacted on the growth of bank loans and also to reduce bias between the data based on P2P platforms and the data based on banking in Indonesia. This is because the time-difference model can reduce the bias from the omitted variables 
(Doan et al., 2015; Nguyen et al., 2017). The control variables used were the macro data relevant in general with the use of loans, such as M2 (money supply) and inflation in Indonesia. The models in panel data regression usually consist of pooled OLS, fixed effect and random effect. To check which model was the most suitable between the fixed effect and random effect models, the Hausman test was used (Biyase \& Zwane, 2015; Pillai, 2016). The Lagrange multiplier test was used to select the most suitable model between pooled OLS and the random effect model (Pillai, 2016).

\section{Research results and discussion}

\subsection{Descriptive statistics}

The descriptive statistics in Tables 3, 4 and 5 used the same period, which was during the 15 months from Feb 2018 to April 2019. Table 3 shows the descriptive statistics from the overall provinces, whereby the overall total calculated was 495 observations $(N=495)$ and the between statistics were calculated from 33 provinces $(n=33)$. Table 4 shows the descriptive statistics based on the data in Java island, overall counted at 90 observations $(N=90)$.

Table 3. Descriptive statistics overall (source: author's estimations)

\begin{tabular}{|c|c|c|c|c|c|c|}
\hline \multicolumn{2}{|c|}{ Variable } & Mean & Std Dev & Min & Max & Observations \\
\hline \multirow{3}{*}{ Non MSME } & Overall & 0.00726 & 0.020665 & -0.21069 & 0.11511 & $N=495$ \\
\hline & Between & & 0.004688 & 0.000377 & 0.024158 & $n=33$ \\
\hline & Within & & 0.020141 & -0.21499 & 0.100219 & $T=5$ \\
\hline \multirow{3}{*}{ MSME } & Overall & 0.00992 & 0.017532 & -0.07799 & 0.0997 & $N=495$ \\
\hline & Between & & 0.004383 & -0.0032 & 0.017965 & $n=33$ \\
\hline & Within & & 0.016991 & -0.0763 & 0.093623 & $T=15$ \\
\hline \multirow{3}{*}{$\mathrm{P} 2 \mathrm{P}$} & Overall & 0.18999 & 0.151349 & 0.01405 & 0.76942 & $N=495$ \\
\hline & Between & & 0.003309 & 0.183083 & 0.19153 & $n=33$ \\
\hline & Within & & 0.151314 & 0.012514 & 0.767884 & $T=15$ \\
\hline \multirow{3}{*}{ M2 } & Overall & 0.00477 & 0.009187 & -0.01973 & 0.018227 & $N=495$ \\
\hline & Between & & 0 & 0.004771 & 0.004771 & $n=33$ \\
\hline & Within & & 0.009187 & -0.01973 & 0.018227 & $T=15$ \\
\hline \multirow{3}{*}{ INFL } & Overall & 0.03055 & 0.002688 & 0.0248 & 0.0341 & $N=495$ \\
\hline & Between & & $3.52 \mathrm{E}-18$ & 0.030547 & 0.030547 & $n=33$ \\
\hline & Within & & 0.002688 & 0.0248 & 0.0341 & $T=15$ \\
\hline \multirow{3}{*}{$\mathrm{D}_{\text {HMSME }}$} & Overall & 0.48485 & 0.50028 & - & 0.00000 & $N=495$ \\
\hline & Between & & 0.20701 & 0.06667 & 0.86667 & $n=33$ \\
\hline & Within & & 0.45677 & $(0.38182)$ & 1.41818 & $T=15$ \\
\hline \multirow{3}{*}{$\mathrm{D}_{\text {MSME }}$} & Overall & 0.591919 & 0.491975 & 0 & 1 & $N=495$ \\
\hline & Between & & 0.154342 & 0.3333333 & 0.866667 & $n=33$ \\
\hline & Within & & 0.46786 & -0.274748 & 1.258586 & $T=15$ \\
\hline
\end{tabular}

Table 4. Descriptive statistics in Java Island (source: author's estimations)

\begin{tabular}{|c|c|c|c|c|c|c|}
\hline \multicolumn{2}{|c|}{ Variable } & Mean & Std Dev & Min & Max & Observations \\
\hline \multirow{3}{*}{ Non MSME } & Overall & 0.00760 & 0.014426 & -0.02822 & 0.06915 & $N=90$ \\
\hline & Between & & 0.0025 & 0.004884 & 0.01162 & $n=6$ \\
\hline & Within & & 0.014243 & -0.0273 & 0.06777 & $T=15$ \\
\hline \multirow{3}{*}{ MSME } & Overall & 0.01083 & 0.014505 & -0.0337 & 0.07104 & $N=90$ \\
\hline & Between & & 0.002157 & 0.0084 & 0.01451 & $n=6$ \\
\hline & Within & & 0.014369 & -0.03127 & 0.07347 & $T=15$ \\
\hline \multirow{3}{*}{$\mathrm{P} 2 \mathrm{P}$} & Overall & 0.18308 & 0.042669 & 0.11366 & 0.27019 & $N=90$ \\
\hline & Between & & 0 & 0.183083 & 0.18308 & $n=6$ \\
\hline & Within & & 0.042669 & 0.11366 & 0.27019 & $T=15$ \\
\hline \multirow{3}{*}{ M2 } & Overall & 0.00477 & 0.009229 & -0.01973 & 0.01823 & $N=90$ \\
\hline & Between & & 0 & 0.004771 & 0.00477 & $n=6$ \\
\hline & Within & & 0.009229 & -0.01973 & 0.01823 & $T=15$ \\
\hline
\end{tabular}


End of Table 4

\begin{tabular}{|c|c|c|c|c|c|c|}
\hline \multicolumn{2}{|c|}{ Variable } & Mean & Std Dev & Min & $\operatorname{Max}$ & Observations \\
\hline \multirow{3}{*}{ Infl } & Overall & 0.03055 & 0.002701 & 0.0248 & 0.0341 & $N=90$ \\
\hline & Between & & $3.80 \mathrm{E}-18$ & 0.030547 & 0.03055 & $n=6$ \\
\hline & Within & & 0.002701 & 0.0248 & 0.0341 & $T=15$ \\
\hline \multirow{3}{*}{$\mathrm{D}_{\text {HMSME }}$} & Overall & 0.47778 & 0.502304 & 0 & 1 & $N=90$ \\
\hline & Between & & 0.160093 & 0.2 & 0.6 & $n=6$ \\
\hline & Within & & 0.480325 & -0.12222 & 1.27778 & $T=15$ \\
\hline \multirow{3}{*}{$\mathrm{D}_{\mathrm{MSME}}$} & Overall & 0.55556 & 0.499688 & 0 & 1 & $N=90$ \\
\hline & Between & & 0.137706 & 0.333333 & 0.66667 & $n=6$ \\
\hline & Within & & 0.483433 & -0.11111 & 1.22222 & $T=15$ \\
\hline
\end{tabular}

Table 5. Descriptive statistics outside of Java Island (source: author's estimations)

\begin{tabular}{|c|c|c|c|c|c|c|}
\hline \multicolumn{2}{|c|}{ Variable } & Mean & Std Dev & Min & Max & Observations \\
\hline \multirow{3}{*}{ Non MSME } & Overall & 0.00719 & 0.021824 & -0.21069 & 0.11511 & $N=405$ \\
\hline & Between & & 0.005081 & 0.000377 & 0.024158 & $n=27$ \\
\hline & Within & & 0.021245 & -0.21507 & 0.100143 & $T=15$ \\
\hline \multirow{3}{*}{ MSME } & Overall & 0.00972 & 0.018145 & -0.07799 & 0.0997 & $N=405$ \\
\hline & Between & & 0.004746 & -0.0032 & 0.017965 & $n=27$ \\
\hline & Within & & 0.017536 & -0.0765 & 0.093421 & $T=15$ \\
\hline \multirow{3}{*}{$\mathrm{P} 2 \mathrm{P}$} & Overall & 0.19153 & 0.166119 & 0.01405 & 0.76942 & $N=405$ \\
\hline & Between & & 0 & 0.19153 & 0.19153 & $n=27$ \\
\hline & Within & & 0.166118 & 0.01405 & 0.76942 & $T=15$ \\
\hline \multirow{3}{*}{ M2 } & Overall & 0.00477 & 0.009189 & -0.01973 & 0.018227 & $N=405$ \\
\hline & Between & & 0 & 0.004771 & 0.004771 & $n=27$ \\
\hline & Within & & 0.009189 & -0.01973 & 0.018227 & $T=15$ \\
\hline \multirow{3}{*}{ Infl } & Overall & 0.03055 & 0.002689 & 0.0248 & 0.0341 & $N=405$ \\
\hline & Between & & 0 & 0.030547 & 0.030547 & $n=27$ \\
\hline & Within & & 0.002689 & 0.0248 & 0.0341 & $T=15$ \\
\hline \multirow{3}{*}{$\mathrm{D}_{\text {HMSME }}$} & Overall & 0.48642 & 0.500434 & 0 & 1 & $N=405$ \\
\hline & Between & & 0.218632 & 0.066667 & 0.866667 & $n=27$ \\
\hline & Within & & 0.451985 & -0.38025 & 1.419753 & $T=15$ \\
\hline \multirow{3}{*}{$\mathrm{D}_{\mathrm{MSME}}$} & Overall & 0.6 & 0.490504 & 0 & 1 & $N=405$ \\
\hline & Between & & 0.159057 & 0.333333 & 0.866667 & $n=27$ \\
\hline & Within & & 0.464943 & -0.26667 & 1.266667 & $\mathrm{~T}=15$ \\
\hline
\end{tabular}

The between statistics calculated included six provinces on Java Island $(n=6)$. Table 5 shows the descriptive statistics from the 405 observations outside of Java Island, ( $\mathrm{N}=$ $405)$ and 27 provinces used for this $(n=27)$.

\subsection{Model testing and research results}

In this section, we will explain the model testing to determine the model used in this study. Then we will present the results of the research according to the model used.

\subsubsection{Model testing}

The Chow test, Hausman test and the Breusch Pagan Lagrangian multiplier tests in Table 6 were conducted on all of the variables and they yielded insignificant results, therefore the model used in this study was pooled OLS. The multicollinearity test using VIF also showed that there was no multicollinearity issue. The Breusch-Pagan/ Cook-Weisberg tests were used to test the heteroscedasticity and the result was that there was heteroscedasticity in the MSME loan growth parameter overall and in the loan growth of non-MSME and MSME, therefore robust standard error was used to resolve the issue.

The Chow test, Hausman test and the Breusch Pagan Lagrangian multiplier tests for model testing with dummy in Table 7 yielded insignificant results; therefore, the models are estimated using a pooled OLS. The multicollinearity test using VIF also showed that there was no multicollinearity issue. The Breusch-Pagan/Cook-Weisberg tests were used to test the heteroscedasticity, and Wooldridge 
Table 6. Model Testing without Dummy (source: author's estimations)

\begin{tabular}{|c|c|c|c|c|c|c|}
\hline & \multicolumn{2}{|c|}{ Overall } & \multicolumn{2}{|c|}{ Java Island } & \multicolumn{2}{|c|}{ Outside Java Island } \\
\hline & $\triangle$ Non MSME & $\triangle \mathrm{MSME}$ & $\begin{array}{l}\triangle \text { Non } \\
\text { MSME }\end{array}$ & $\triangle \mathrm{MSME}$ & $\begin{array}{l}\Delta \text { Non } \\
\text { MSME }\end{array}$ & $\triangle \mathrm{MSME}$ \\
\hline Chow Test $($ Prob > F) & 0.7770 & 0.3113 & 0.7311 & 0.7817 & 0.7064 & 0.2332 \\
\hline Hausman Test & 1.0000 & 0.9975 & 1.0000 & 1.0000 & 1.000 & 1.0000 \\
\hline Breusch Pagan Lagrangian multiplier test & 1.0000 & 0.3693 & 1.0000 & 1.0000 & 1.000 & 0.2836 \\
\hline VIF & 1.02 & 1.02 & 2.26 & 2.26 & 1.02 & 1.02 \\
\hline \multirow{2}{*}{ Breusch-Pagan/Cook-Weisberg test } & \multirow{2}{*}{0.5210} & 0.0192 * & $0.0078^{*}$ & 0.032 * & \multirow{2}{*}{0.1318} & \multirow{2}{*}{0.0550} \\
\hline & & & roscedast & & & \\
\hline Wooldridge test & 0.9364 & 0.7888 & 0.1227 & 0.2718 & 0.8668 & 0.9706 \\
\hline
\end{tabular}

Note: ${ }^{\star}$ significant at the 0.05 level.

Table 7. Model testing with Dummy (source: author's estimations)

\begin{tabular}{|c|c|c|c|c|c|c|}
\hline & \multicolumn{2}{|c|}{ Overall } & \multicolumn{2}{|c|}{ Java Island } & \multicolumn{2}{|c|}{ Outside Java Island } \\
\hline & $\triangle$ Non MSME & $\triangle \mathrm{MSME}$ & $\triangle$ Non MSME & $\triangle \mathrm{MSME}$ & $\Delta$ Non MSME & $\triangle \mathrm{MSME}$ \\
\hline Chow Test $($ Prob $>$ F) & 0.9599 & 0.9331 & 0.9967 & 0.7390 & 0.8831 & 0.9329 \\
\hline Hausman Test & 0.4247 & 0.9872 & 0.9993 & 0.9857 & 0.3290 & 0.9889 \\
\hline Breusch Pagan Lagrangian multiplier test & 1.0000 & 1.0000 & 1.0000 & 1.0000 & 1.0000 & 1.0000 \\
\hline VIF & 1.14 & 1.14 & 1.91 & 1.91 & 1.15 & 1.15 \\
\hline \multirow{2}{*}{ Breusch-Pagan/Cook Weisberg test } & 0.6282 & 0.4371 & $0.0016^{*}$ & 0.0001 & 0.5456 & 0.9801 \\
\hline & & & \multicolumn{2}{|c|}{ (Heteroscedasticity) } & & \\
\hline Wooldridge test & 0.2457 & 0.5998 & $\begin{array}{c}0.0018^{*} \\
\text { (autocorrelation) }\end{array}$ & 0.3600 & 0.1472 & 0.5914 \\
\hline
\end{tabular}

Note: ${ }^{\star}$ significant at the 0.05 level.

test was used to test the autocorrelation. The result shows that there was heteroscedasticity in the non-MSME and MSME growth parameter in Java Island, and there was autocorrelation in the non-MSME growth parameter in Java Island; therefore, robust standard error was used to resolve the issue.

\subsubsection{Research results}

The results from the panel data regression in Table 8 were consistent, be it overall, in the Java region and outside
Java, whereby despite the rapid growth of P2P lending in Indonesia, it does not have a significant impact on the growth of non-MSME loans. The coefficient for P2P loan growth showed a positive direction for the growth of non-MSME loans. Similarly, the growth of MSME loans yielded consistent results for all regions, which was that the growth in P2P lending had a negative impact on the growth of MSME loans in each region. However, control variable M2 (money supply) has a positive and significant impact on each of the loan variables and control variable

Table 8. Panel data regression test results (source: author's estimations)

\begin{tabular}{|l|c|c|c|c|c|c|}
\hline \multirow{2}{*}{} & \multicolumn{2}{|c|}{ Overall } & \multicolumn{2}{|c|}{ Java Island } & \multicolumn{3}{c|}{ Outside Java Island } \\
\cline { 2 - 7 } & $\Delta$ Non MSME & $\Delta$ MSME & $\Delta$ Non MSME & $\Delta$ MSME & $\Delta$ Non MSME & $\Delta$ MSME \\
\hline \multirow{2}{*}{ Constant } & -0.0066 & -.00018 & -0.0335 & -0.0422 & 0.0004 & 0.0022 \\
& $(0.524)$ & $(0.817)$ & $(0.061)$ & $(0.003)^{*}$ & $(0.972)$ & $(0.818)$ \\
\hline \multirow{2}{*}{$\Delta$ P2P Loans } & 0.0042 & -0.0213 & 0.0302 & -0.1367 & .0039 & -0.0209 \\
& $(0.488)$ & $(0.000)^{*}$ & $(0.620)$ & $(0.003)^{*}$ & $(0.549)$ & $(0.000)^{*}$ \\
\hline$\Delta$ M2 (Money & 0.4923 & 0.6859 & 0.5941 & 1.0000 & 0.4632 & 0.6450 \\
Supply) & $(0.000)^{\star}$ & $(0.000)^{*}$ & $(0.000)^{*}$ & $(0.000)^{*}$ & $(0.000)^{*}$ & $(0.000)^{*}$ \\
\hline Inflation & 0.3512 & 0.41234 & 1.0721 & 2.4019 & 0.1244 & 0.2761 \\
& $(0.307)$ & $(0.127)$ & $(0.185)$ & $(0.001)^{*}$ & $(0.757)$ & $(0.384)$ \\
\hline R Square & 0.0524 & 0.1583 & 0.2413 & 0.3669 & 0.0398 & 0.1390 \\
\hline
\end{tabular}

Note: ${ }^{*}$ significant at the 0.01 level. 
Table 9. Panel data regression test results with dummy (source: author's estimations)

\begin{tabular}{|c|c|c|c|c|c|c|}
\hline & \multicolumn{2}{|c|}{ Overall } & \multicolumn{2}{|c|}{ Java Island } & \multicolumn{2}{|c|}{ Outside Java Island } \\
\hline & $\Delta$ Non MSME & $\Delta \mathrm{MSME}$ & $\Delta$ Non MSME & $\triangle \mathrm{MSME}$ & $\Delta$ Non MSME & $\triangle \mathrm{MSME}$ \\
\hline Constant & $\begin{array}{l}.01003 \\
(0.283)\end{array}$ & $\begin{array}{l}-0.0178 \\
(0.007)^{\star}\end{array}$ & $\begin{array}{l}-0.0371 \\
(0.006)^{\star}\end{array}$ & $\begin{array}{l}-.03593 \\
(0.001)^{\star}\end{array}$ & $\begin{array}{c}0.0205 \\
(0.065)^{* * *}\end{array}$ & $\begin{array}{l}-0.0177 \\
(0.022)^{\star *}\end{array}$ \\
\hline$\triangle \mathrm{P} 2 \mathrm{P}$ Loans & $\begin{array}{c}-0.0067 \\
(0.226)\end{array}$ & $\begin{array}{l}-0.0017 \\
(0.000)^{\star}\end{array}$ & $\begin{array}{c}-0.0312 \\
(0.494)\end{array}$ & $\begin{array}{l}-0.0921 \\
(0.008)^{\star}\end{array}$ & $\begin{array}{c}-0.0073 \\
(0.217)\end{array}$ & $\begin{array}{l}-0.0169 \\
(0.000)^{\star}\end{array}$ \\
\hline $\begin{array}{l}\Delta \mathrm{M} 2 \text { (Money } \\
\text { Supply) }\end{array}$ & $\begin{array}{c}0.5637 \\
(0.000)^{*}\end{array}$ & $\begin{array}{c}0.6523 \\
(0.000)^{\star}\end{array}$ & $\begin{array}{l}0.7272 \\
(0.000)^{*}\end{array}$ & $\begin{array}{c}0.8316 \\
(0.000)^{\star}\end{array}$ & $\begin{array}{c}0.5294 \\
(0.000)^{*}\end{array}$ & $\begin{array}{c}0.6397 \\
(0.000)^{\star}\end{array}$ \\
\hline Inflation & $\begin{array}{l}0.1846 \\
(0.545)\end{array}$ & $\begin{array}{c}0.5058 \\
(0.020)^{\star *}\end{array}$ & $\begin{array}{c}1.7519 \\
(0.005)^{\star}\end{array}$ & $\begin{array}{c}1.6634 \\
(0.001)^{\star}\end{array}$ & $\begin{array}{c}-0.1175 \\
(0.743)\end{array}$ & $\begin{array}{c}0.4697 \\
(0.060)^{\star * *}\end{array}$ \\
\hline $\mathrm{D}_{\text {HMSME }}$ & $\begin{array}{c}0.0057 \\
(0.002)^{*}\end{array}$ & $\begin{array}{c}0.0132 \\
(0.000)^{*}\end{array}$ & $\begin{array}{l}0.0065 \\
(0.010)^{*}\end{array}$ & $\begin{array}{c}0.0101 \\
(0.000)^{\star}\end{array}$ & $\begin{array}{c}0.0054 \\
(0.013)^{\star *}\end{array}$ & $\begin{array}{c}0.0137 \\
(0.000)^{\star}\end{array}$ \\
\hline $\mathrm{D}_{\mathrm{MSME}}$ & $\begin{array}{l}-0.0213 \\
(0.000)^{*}\end{array}$ & $\begin{array}{l}.0102859 \\
(0.000)^{*}\end{array}$ & $\begin{array}{l}-0.0173 \\
(0.000)^{*}\end{array}$ & $\begin{array}{c}0.0072 \\
(0.000)^{\star}\end{array}$ & $\begin{array}{l}-0.0225 \\
(0.000)^{*}\end{array}$ & $\begin{array}{c}0.0109 \\
(0.000)^{*}\end{array}$ \\
\hline R Square & 0.2560 & 0.4766 & 0.5286 & 0.6090 & 0.2416 & 0.4717 \\
\hline
\end{tabular}

Note: ${ }^{\star}$ significant at the 0.01 level, ${ }^{* *}$ significant at the 0.05 level, ${ }^{* *}$ significant at the 0.10 level.

inflation has a positive coefficient for each region. However, it only has a significant and positive impact on the growth of MSME loans in Java Island. Hypothesis which stated that $\mathrm{P} 2 \mathrm{P}$ loans have a positive impact on banks in the early regime of FinTech growth did not occur in Indonesia. The opposite of the hypothesis was supported, whereby we proved that $\mathrm{P} 2 \mathrm{P}$ loan growth is significantly negative when related to the growth of lending from banks to MSME debtors.

The results from the panel data regression test with dummy in Table 9 were consistent, P2P loan growth does not have a significant impact on the growth of non-MSME loans. Similarly, impact P2P lending to the growth of MSME loans yielded consistent results for all regions, which was that the growth in P2P lending had a negative and significant impact on the growth of MSME loans in each region. However, control variable M2 (money supply) has a positive and significant impact on each of the loan variables, and inflation variable has a significant impact on the growth of MSME loans in each region, and on the growth of non-MSME loans on Java Island. Dummy variables (DHMSME and DHSME) have a significant impact on the growth of non-MSME loans and MSME loans in each region.

\section{Discussion}

On average, the financial inclusion in Indonesia during 2013-2018 was low. Figure 3 shows that the average of the bank loan ratio on the gross domestic income was only $35.37 \%$. The high number of the unbanked population offers a great opportunity for FinTech to use technology in order to give lending access to the niche market without being hindered by bricks and mortar. Therefore, it is very relevant that the results of this study show that the growth of P2P lending (be it within or outside of Java) does not have significant impact on non-MSME loans. This is because the target market for FinTech in the initial growth stage (entrant's disruptive trajectory) is to reach areas that are not yet served by banks (niche market) within or outside of Java. Incumbents ignore the new entrants because their existing business is not threatened. Even if they want to enter the new or niche market, the incumbents may not have the advantage of the low-end disruption (Hang et al., 2011) because, it is not really feasible between the costs (effort) and benefits.

In addition, Figure 4 shows that MSME loans are not the main market for commercial banking; the highest ratio of MSME loans to total commercial bank loans is still too small at only $18.46 \%$. Whereas, based on data from the Ministry of Co-operatives and small medium-sized

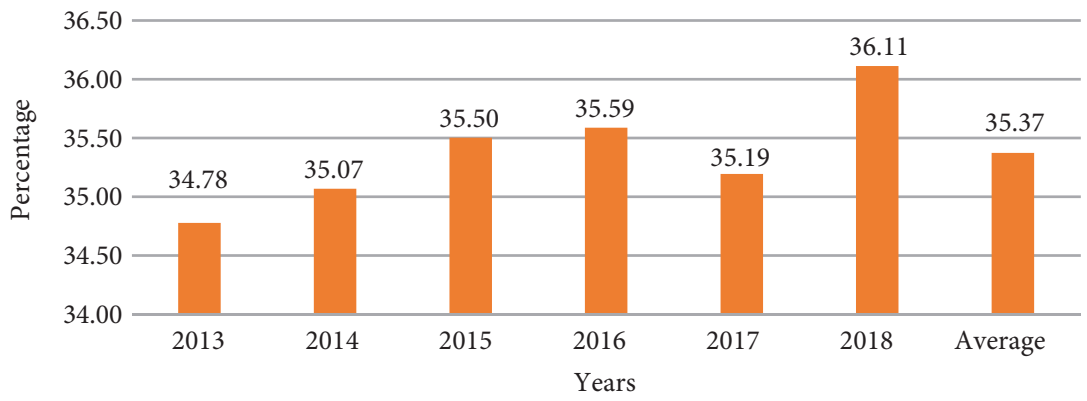

Figure 3. Bank loans on GDI (in \%) (source: Bank Indonesia, 2019) 


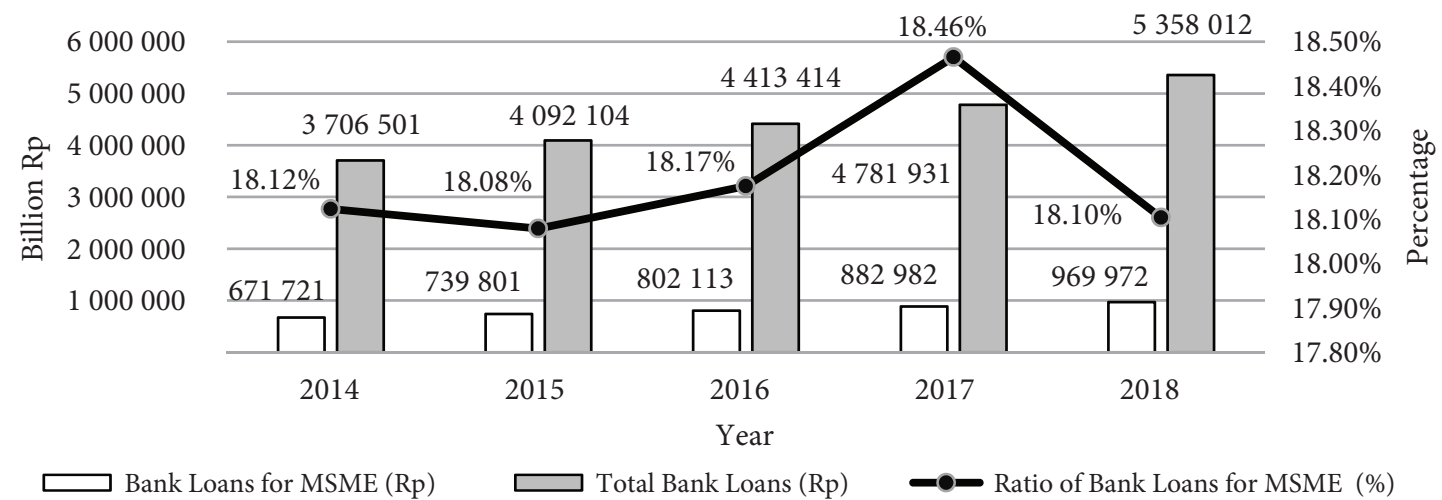

Figure 4. Ratio of bank loans for MSME to total commercial bank loans for MSME (source: Bank Indonesia, 2019)

enterprises (SMEs), SMEs play an important role in economic growth in Indonesia, which accounts for nearly $97 \%$ of domestic work and $56 \%$ of total business (Organisation for Economic Co-operation and Development, 2018). Therefore, this is an opportunity for P2P platforms to grab the market, starting from MSME loans as a neglected market by incumbents.

Zhang et al. (2019) state that P2P loan platforms do not reach a size to compete with banks because they are too small, but our research gave a more detailed statement which is that, while they have not yet reached the size to compete with bank loans for non-MSME debtors, this is not the case with bank loans for MSME. In accordance with the study results, it showed that the P2P loans have a significant and negative impact on the MSME loans disbursed by banks. Banks are very careful and selective when it comes to disbursing loans and, therefore, banks will provide loans for debtors with a lower risk and with easier access to the banks to allow them to access the company information (financial reports); low non-performing loans or better asset quality will result in higher bank performance (Nuhiu, Hoti, \& Bektashi, 2017). MSME debtors are often viewed as having a higher risk and there are reports that they are relatively harder to access or they are not informative enough. This is because they are not based on generally accounting according to accepted principles (just a simple record or bookkeeping). On the other hand, the P2P platform continues to grow and is able to serve the MSME business segment. It also facilitates easier requirements when it concerns access to loans. This is reasonable, as P2P loans can have an impact on the potential or current MSME debtors who are concerned with time and efficiency concerning the move to the lending facility provided by the P2P platform (Zhang et al., 2019).

We can see the alignment between the $\mathrm{P} 2 \mathrm{P}$ growth patterns in Indonesia with the disruptive innovation process (entrant's disruptive trajectory). Entrant firms with fewer resources can displace established firms by targeting a market segment that was previously ignored. This is because usually, established firms will tend to focus on the development or innovation of the main and most beneficial area (sustaining innovation). FinTechs (P2P platform) exploit technology to create new product or an old product in new ways. As with the disruptive innovation process, FinTech (P2P platform) entered the market through segments that were not previously the focus of banking, which consist of the unbanked population (niche market) and MSME.

Innovation is the most important driver for firms (banks) to achieve long-term business growth and to win over the competition (Suhardianto \& Godigbe, 2018). As long as P2P loans have not yet entered the domain of non-MSME debtors, the traditional banking position is still relatively safe. Related parties in the banking sector should respond to the potential threat from FinTech to turn it into an opportunity to maintain or improve the competitive advantage of banks through sustaining innovation, the merger/acquisition of FinTech start-ups or creating subsidiaries (division) to develop in the FinTech market. Change cannot be a threat to the banking managers, but it can instead be a way to develop new opportunities (Kohnová, Papula, \& Salajová, 2019).

The bank's response to FinTech should start from now, when FinTech has just started to grow rapidly. This is because if FinTech can penetrate the main market segment of the established banks (incumbents), then the bank management will face difficulties in overcoming the competition. This is the same as Zhang et al. (2019) state in that when P2P loan balances are bigger, P2P loan balances have a negative impact on bank loan balances. Therefore, the little giant of FinTech has the potential to become a big giant in the future. Beware, embrace and manage FinTech; this is to be the future of the financial landscape without bricks and mortar.

\section{Conclusions}

Indonesian society has given positive feedback related to the emergence of Fintech / P2P platforms, and this was proven by the rapid growth of the target market of P2P lending in Indonesia. However, the P2P platform can potentially be a disruptive innovation or an opportunity for banks (financing institutions). In this paper, the authors put forward an empirical evaluation of the relationship 
between the growth of P2P lending and the growth of bank loans using a panel data regression.

This study showed a similar pattern to the disruptive innovation process with the entrance to the market being through the entrant's disruptive trajectory. The study showed consistent results, be it within Java Island (which has the highest gross domestic product distribution) or outside of Java Island. We found that the growth in P2P lending does not have an impact on the growth of nonMSME debtors, which are the main target market for banks. Therefore it can be concluded that the P2P platform entered into a different market (niche market) from that of the banks, namely the unbanked population. On the contrary, P2P lending has a significant and negative impact on the growth of bank loans for MSME debtors who were not the main focus of the banks.

P2P loans as a financial innovation must be encouraged by the Indonesian government because they help to solve the problem of financing MSME debtors and unbanked consumers. This is as well as strengthening the bank's competitive awareness and encouraging innovation (FinTech innovation) in their products and service quality in order to improve their marketing performance. This will enhance the profitability of the banks (Sloboda, Dunas, \& Limański, 2018; Tjahjadi, Shanty, \& Soewarno, 2019; Tjahjadi \& Soewarno, 2018). Meanwhile, an effective regulatory system must be designed to supervise P2P loans in Indonesia, in addition to a regulatory system that does not hamper or destroy the existence of the banking sector.

Short datasets are the main challenge faced by the study. This limitation prevented the use of more indicators to develop the impact of $\mathrm{P} 2 \mathrm{P}$ on bank loans comprehensively. In addition, future research can investigate the relationship between P2P and other variables such as financial inclusion and shadow banking, thus deepening the understanding of this important issue. Then, future research can undertake an analysis of the FinTech effect by studying various countries. This is because other countries may have different structures and impacts in the banking sector. In addition, future research can examine the effect of P2P lending on the loans channelled by other financial institutions.

\section{References}

Abir, M., Raoudha, D., \& Emna, R. (2016). Interaction effect between product and process innovation: The case of Tunisian banks. Banks and Bank Systems, 11(1). https://doi.org/10.21511/bbs.11(1).2016.07

Anagnostopoulos, I. (2018). Fintech and regtech: impact on regulators and banks. Journal of Economics and Business, 100, 7-25. https://doi.org/10.1016/j.jeconbus.2018.07.003

Bank Indonesia. (2019). Statistik Sistem Keuangaan Indonesia.

Biyase, M., \& Zwane, T. (2015). Economic growth and government expenditures in Africa: panel data analysis. Environmental Economics, 6(3), 15-19. https://businessperspectives. org/images/pdf/applications /publishing/ templates/article/ assets/6792/ee_2015_03_Biyase.pdf
Christensen, C. M. (1997). Innovator's dilemma. Boston, Massachusetts: Harvard Business School Press.

Christensen, C. M., Altman, E. J., Mcdonald, R., \& Palmer, J. (2016). Disruptive Innovation: Intellectual History and Future Paths (No. 17-057). Harvard Business School.

Christensen, C. M., \& Raynor, M. E. (2003). The innovator's solution. Boston, Massachusetts: Harvard Business School Publishing Corporation.

Christensen, C. M., Raynor, M., \& McDonald, R. (2015). What is disruptive innovation? Harvard Business Review, (December).

Coetzee, J. (2018). Strategic implications of Fintech on South African retail banks. South African Journal of Economic and Management Sciences, 21(1).

https://doi.org/10.4102/sajems.v21i1.2455

Das, P., Verburg, R., Verbraeck, A., \& Bonebakker, L. (2018). Barriers to innovation within large financial services firms An in-depth study into disruptive and radical innovation projects at a bank. European Journal of Innovation Management, 21(1), 96-112. https://doi.org/10.1108/EJIM-03-2017-0028

Das, S. (2017). Banking on disruption: digitization, FinTech and the future of retail banking. Clayton Christensen Institute and Tata Consultancy Services.

Doan, T., Nguyen, S., Vu, H., Tran, T., \& Lim, S. (2015). Does rising import competition harm local firm productivity in less advanced economies? Evidence from the Vietnam's manufacturing sector. The Journal of International Trade \& Economic Development, (May), 37-41. https://doi.org/10.1080/09638199.2015.1035739

Gai, K., Qiu, M., \& Sun, X. (2018). A survey on FinTech. Journal of Network and Computer Applications, 103, 262-273.

https://doi.org/10.1016/j.jnca.2017.10.011

Govindarajan, V., \& Kopalle, P. K. (2006). Disruptiveness of innovations: measurement and an assesment of reliability and validity. Strategic Management Journal, 27(July 2005), 189199. https://doi.org/10.1002/smj.511

Gupta, A., \& Xia, C. (2018). A Paradigm shift in banking: unfolding Asia's FinTech adventures. In Banking and Finance Issues in Emerging Markets (pp. 215-254). Emerald Publishing Limited. https://doi.org/10.1108/S1571-038620180000025010

Hang, C. C., Chen, J., \& Yu, D. (2011). An assessment framework for disruptive innovation. Foresight, 13(5), 4-13. https://doi. org/10.1108/14636681111170185

Iman, N. (2019). Traditional banks against fintech startups: a field investigation of a regional bank in Indonesia. Banks and Bank Systems, 14(3), 20-33.

https://doi.org/10.21511/bbs.14(3).2019.03

Jagtiani, J., \& Lemieux, C. (2018). Do fintech lenders penetrate areas that are underserved by traditional banks? Journal of Economics and Business, 100(March), 43-54. https://doi. org/10.1016/j.jeconbus.2018.03.001

Keuangan, O. J. (2019). Ikhtisar Data Keuangan Fintech (Peer To Peer Lending) Periode April 2019. Otoritas Jasa Keuangan.

King, A. A., \& Baatartogtokh, B. (2015). How useful is the theory of disruptive innovation? H. MITSloan Management Review, 57(1).

Konsumen, Departemen Pengembangan UMKM dan Perlindungan. (2019). Laporan Perkembangan Kredit UMKM Triwulan IV 2018. https://www.bi.go.id/id/umkm/kredit/laporan/ Pages/Laporan-Perkembangan-Kredit-UMKM-TriwulanIV-2018.aspx

Kohnová, L., Papula, J., \& Salajová, N. (2019). Internal factors supporting business and technological transformation in the context of industry 4.0. Business: Theory and Practice, 20, 137-145. https://doi.org/10.3846/btp.2019.13 
Lavryk, A. (2016). P2P lending as an alternative to bank lending in Ukraine. Banks and Bank Systems, 11(4), 20-30. https://doi.org/10.21511/bbs.11(4).2016.02

Lee, I., \& Shin, Y. J. (2018). Fintech: ecosystem, business models, investment decisions, and challenges. Business Horizons, 61(1), 35-46. https://doi.org/10.1016/j.bushor.2017.09.003

Li, Y., Spigt, R., \& Swinkels, L. (2017). The impact of FinTech start-ups on incumbent retail banks' share prices. Financial Innovation, 3(1). https://doi.org/10.1186/s40854-017-0076-7

Montgomery, N., Squires, G., \& Syed, I. (2018). Disruptive potential of real estate crowdfunding in the real estate project finance industry A literature review. Property Management, 36(5), 597-619. https://doi.org/10.1108/PM-04-2018-0032

Nguyen, T. Le, Vu Van, H., Nguyen, L. D., \& Tran, T. Q. (2017). Does rising import competition harm Vietnam's local firm employment of the 2000s? Economic Research, 30(1), 18821895. https://doi.org/10.1080/1331677X.2017.1392883

Nuhiu, A., Hoti, A., \& Bektashi, M. (2017). Determinants of commercial banks profitability through analysis of financial performance indicators: Evidence from Kosovo. Business: Theory and Practice, 18, 160-170. https://doi.org/10.3846/btp.2017.017

Organisation for economic co-operation and development. (2018). SME and Entrepreneurship Policy in Indonesia 2018.

Pillai, V. (2016). Panel data analysis with Stata (Part 1 fixed effects and random effects models) (No. 76869). https://mpra.ub.uni-muenchen.de/76869/

Ramlall, I. (2018). FinTech and the financial stability board. Understanding Financial Stability ((The Theory and Practice of Financial Stability), 1, 71-81. https://doi.org/10.1108/978-1-78756-833-420181016

Rasool, F., Koomsap, P., Afsar, B., \& Panezai, B. A. (2018). A framework for disruptive innovation. Foresight, 20(3). https://doi.org/10.1108/FS-10-2017-0057

Romānova, I., \& Kudinska, M. (2017). Banking and Fintech: a challenge or opportunity? Contemporary Issues in Finance: Current Challenges from Across Europe, 98, 21-35. https://doi.org/10.1108/S1569-375920160000098002

Ryu, H.-S. (2018). What makes users willing or hesitant to use Fintech?: the moderating effect of user type. Industrial Management and Data Systems, 118(3), 541-569. https://doi.org/10.1108/IMDS-07-2017-0325

Satell, G. (2017). Mapping innovation. McGraw-Hill Education. Sloboda, L., Dunas, N., \& Limański, A. (2018). Contemporary challenges and risks of retail banking development in
Ukraine. Banks and Bank Systems, 13(1), 88-97. https://doi.org/10.21511/bbs.13(1).2018.09

Song, P., Chen, Y., Zhou, Z., \& Wu, H. (2018). Performance analysis of peer-to-peer online lending platforms in China. Sustainability. https://doi.org/10.3390/su10092987

Statistik, B. P. (2019). Pertumbuhan Ekonomi Indonesia Triwulan IV-2018.

Stern, C., Makinen, M., \& Qian, Z. (2017). FinTechs in China with a special focus on peer to peer lending. Journal of Chinese Economic and Foreign Trade Studies, 10(3), 215-228. https://doi.org/10.1108/JCEFTS-06-2017-0015

Suhardianto, N., \& Godigbe, B. G. (2018). Employee career constraint and innovation. SSRN Electronic Journal, 1-41. https://doi.org/10.2139/ssrn.2946851

Tan, Y. (2017). The impacts of competition and shadow banking on profitability: Evidence from the Chinese banking industry. North American Journal of Economics and Finance, 42, 89-106. https://doi.org/10.1016/j.najef.2017.07.007

Tjahjadi, B., Shanty, H. M., \& Soewarno, N. (2019). Innovation, process capital and financial performance: mediating role of marketing performance (evidence from manufacturing industry in Indonesia). Humanities \& Social Sciences Reviews, 7(1), 278-290. https://doi.org/10.18510/hssr.2019.7132

Tjahjadi, B., \& Soewarno, N. (2018). Mediating roles of innovation capability and customer performance in seniority management - financial performance relationship: experience of SOEs in Indonesia. The 2018 International Conference of Organizational Innovation, 2018, 873-885. https://doi.org/10.18502/kss.v3i10.3432

Wu, M., \& Hua, C. (2018). Effects of shadow banking on bank risks from the view of capital adequacy. International Review of Economics and Finance, 1-22. https://doi.org/10.1016/j.iref.2018.09.004

Zakky. (2018). 34 Nama Provinsi di Indonesia dan Ibukotanya Lengkap. https://www.zonareferensi.com/provinsi-di-indonesia/

Zalan, T., \& Toufaily, E. (2017). The promise of fintech in emerging markets: Not as disruptive. Contemporary Economics, 11(4), 415-430. https://doi.org/10.5709/ce.1897-9254.253

Zhang, Z., Hu, W., \& Chang, T. (2019). Nonlinear effects of P2P lending on bank loans in a Panel Smooth Transition Regression model. International Review of Economics and Finance, 59(August 2017), 468-473.

https://doi.org/10.1016/j.iref.2018.10.010 